\title{
Analisis kemampuan argumentasi ilmiah siswa pada materi optik: Problem- based learning berbantuan edu-media simulation
}

\author{
Riwayani Riwayani *, Riki Perdana, Ratna Sari, Jumadi Jumadi, Heru Kuswanto \\ Program Studi Pendidikan Fisika, Program Pascasarjana, Universitas Negeri Yogyakarta. \\ Jalan Colombo No. 1, Karangmalang, Yogyakarta 55281, Indonesia. \\ * Coressponding Author. E-mail: riwayani95 @ gmail.com
}

Received: 21 December 2018; Revised: 11 February 2019; Accepted: 28 February 2019

\begin{abstract}
Abstrak
Terdapat banyak model pembelajaran yang diterapkan untuk menganalisis kemampuan argumentasi ilmiah siswa. Namun, belum banyak model yang diintegrasikan dengan pembelajaran berbasis simulasi online untuk meningkatkan kemampuan argumentasi ilmiah siswa. Padahal, saat ini ada banyak website simulasi online yang diterbitkan oleh lembaga pendidikan atau universitas di tingkat internasional dan jarang digunakan dalam penelitian. Penelitian ini mengintegrasikan model pembelajaran inovatif dengan pembelajaran berbasis online simulation untuk meningkatkan kemampuan argumentasi ilmiah siswa. Website simulasi yang digunakan adalah Edu-media simulation. Dalam website ini ada banyak simulasi fisika yang disediakan, tetapi belum banyak penelitian yang menerapkan simulasi ini. Penelitian ini dilakukan dengan kuasi eksperimen yang terdiri dari satu kelas eksperimen dengan sampel 25 siswa kelas XI MIA 3 di SMA Negeri 1 Prambanan Yogyakarta. Argumentasi ilmiah siswa diukur melalui instrumen tes uraian. Data argumentasi ilmiah siswa dianalisis menggunakan paired sample t-test dan pola argumentasi Toulmin (TAP). Hasil penelitian menunjukkan bahwa PBL berbantuan edu-media simulation dapat meningkatkan kemampuan argumentasi ilmiah siswa baik secara kuantitatif maupun kualitatif. Ini ditunjukkan dengan nilai t value $11.051<-1.711$ bahwa terdapat perbedaan nilai rata-rata argumentasi pada pre-test (17) dan post-test (47). Dalam hal ini, siswa sudah mampu membuat klaim yang tegas dengan menyajikan bukti dan alasan yang mendukung klaim.
\end{abstract}

Kata Kunci: edu-media simulation, PBL, argumentasi ilmiah

\section{Analyzing students' scientific argumentation skill in optic: Problem-based learning assisted edu-media simulation}

\begin{abstract}
There are many learning models applied to analyze the ability of students' scientific argumentation. However, not many models have been integrated with online simulation-based learning to improve students' scientific argumentation skills. In fact, there are currently many online simulation websites published by educational institutions or international universities and rarely used in research. This research integrates innovative learning models with online simulation-based learning to improve students' scientific argumentation skills. The simulation website used is Edu-media simulation. In this website there are many physics simulations provided, but not many studies have applied this simulation. This research was conducted with a quasiexperimental consisting of one experimental class with a sample of 25 XI MIA 3 graders in Prambanan High School 1 Yogyakarta. Students' scientific arguments are measured through a description test instrument. Students' scientific argumentation data were analyzed using paired sample t-test and Toulmin argumentation patterns (TAP). The results showed that PBL assisted by edu-media simulation can improve students' scientific argumentation ability both quantitatively and qualitatively. This is indicated by the value of $t$ value $-11.051<-1.711$ that there are differences in the average value of argumentation in the pre-test (17) and post-test (47). In this case, students have been able to make assertive claims by presenting evidence and reasons that support the claim.
\end{abstract}

Keywords: edu-media simulation, problem-based learning, scientific argumentation skill

How to Cite: Riwayani, R., Perdana, R., Sari, R., Jumadi, J., \& Kuswanto, H. (2019). Analisis kemampuan argumentasi ilmiah siswa pada materi optik: Problem-based learning berbantuan edu-media simulation. Jurnal Inovasi Pendidikan IPA, 5(1), 45-53. doi:https://doi.org/10.21831/jipi.v5i1.22548

doi https://doi.org/10.21831/jipi.v5i1.22548 


\section{PENDAHULUAN}

Di Abad 21 terdapat beberapa kemampuan yang harus dimiliki oleh siswa. Satu di antara kemampuan tersebut adalah kemampuan berkomunikasi yang efektif (Saavedra \& Opfer, 2012). Untuk mendukung hal tersebut, siswa harus memiliki kemampuan argumentasi ilmiah yang baik. Hal ini dikarenakan kemampuan argumentasi ilmiah dapat mendukung perkembangan kemampuan Abad 21 siswa (Clark et al., 2010) seperti berpikir kritis, melakukan refleksi dan evaluasi terhadap alasan (Bathgate, Crowell, Schunn, Cannady, \& Dorph, 2015). Selain itu, kemampuan argumentasi ilmiah membantu siswa dalam pengambilan keputusan yang tepat ketika berhadapan dengan isu sosial ilmiah (Yacoubian \& Khishfe, 2018). Selain itu, argumentasi ilmiah telah terbukti menjadi suatu kemampuan yang dapat membantu guru dan siswa dalam mencapai tujuan pembelajaran (Katsh-Singer, Mcneill, \& Loper, 2016). Oleh karena itu, kemampuan argumentasi ilmiah siswa masih harus terus dikaji dan ditingkatkan.

Berbagai penelitian telah dilakukan untuk menyelidiki kemampuan argumentasi ilmiah siswa. Kemampuan argumentasi ilmiah dapat melibatkan siswa dalam aktivitas ilmiah yang kompleks saat mereka membangun dan membenarkan klaim pengetahuan (Berland \& McNeill, 2010). Aktivitas argumentasi juga dapat dikembangkan melalui pemahaman konsep ilmiah siswa (Heng, Surif, \& Seng, 2015). Temuan lain, untuk meningkatkan kemampuan argumentasi ilmiah siswa, perlu mempertimbangkan tingkat pengalaman dan pengetahuan yang mereka miliki (von Aufschnaiter, Erduran, Osborne, \& Simon, 2008). Kemampuan argumentasi ilmiah yang telah diselidiki hampir di semua bidang pelajaran sains, termasuk fisika.

Pada pelajaran fisika, kemampuan argumentasi ilmiah di terapkan di beberapa materi pengukuran (Mubarok, Muslim, \& Danawan, 2016), Hukum Newton (Muliardi, Supeno, \& Bektiarso, 2018), kalor (Putri, 2018), dan termodinamika (Sudarmo, Lesmono, \& Harijanto, 2018). Namun, dari beberapa hasil penelitian ditemukan bahwa kemampuan argumentasi ilmiah siswa masih dikategorikan rendah. Ditemukan hanya sekitar $26.31 \%$ dan $25.19 \%$ sampel yang memiliki kemampuan argumentasi ilmiah masing-masing pada aspek pembenaran dan dukungan (Mubarok et al., 2016). Tidak jauh berbeda dengan temuan sebelumnya, rata-rata kemampuan argumentasi ilmiah siswa hanya sebesar 63.71 dari skor total 100 (Putri, 2018). Tidak hanya itu, bahkan di tingkat mahasiswa pun (calon guru) masih belum memiliki pemahaman yang baik mengenai argumentasi ilmiah (Aydeniz \& Ozdilek, 2015). Oleh sebab itu, strategi belajar untuk meningkatkan kemampuan argumentasi ilmiah masih harus dikembangkan.

Ada banyak strategi yang dapat digunakan untuk meningkatkan kemampuan argumentasi ilmiah. Berdasarkan studi literatur, telah ditemukan beberapa strategi yang digunakan seperti mengembangkan perangkat pembelajaran (instructional content) berbasis argumentasi ilmiah (Berland \& McNeill, 2010), dan membentuk kelompok kecil dalam aktivitas lab (Yun \& Kim, 2015). Pada dasarmya untuk meningkatkan kemampuan argumentasi ilmiah siswa dapat dilakukan melalui aktivitas ilmiah (Manz, 2015). Namun, dari kajian literatur yang dilakukan belum banyak yang memanfaatkan perkembangan teknologi dalam upaya meningkatkan kemampuan argumentasi ilmiah. Padahal penggunaan teknologi dalam pendidikan menjadi sangat penting di era revolusi industri 4.0 ini.

Dalam upaya mengikuti revolusi industri 4.0, ada beberapa strategi belajar yang dilakukan untuk menyelidiki kemampuan argumentasi ilmiah peerta didik. Salah satu strategi belajar yang digunakan adalah menggunakan teknologi (Hsu, Van Dyke, Smith, \& Looi, 2018). Pembelajaran simulasi berbasis game dapat membantu meningkatkan kemampuan argumentasi ilmiah siswa (Ault, Craig-Hare, Frey, Ellis, \& Bulgren, 2015). Selain itu, telah dikembangkan cloud class room (CCR), sistem respon berbasis website yang bertujuan membantu guru dalam mengamati aktivitas argumentasi siswa dalam bentuk kelompik kecil (Chien \& Chang, 2015). Penelitian lain menggunakan respon atau feedback siswa dengan metode online sehingga diperoleh hasil kemampuan argumentasi ilmiah siswa (Zhu et al., 2017). Dari hasil penelitian-penelitian tersebut, menunjukkan bahwa pembelajaran menggunakan teknologi memberi pengaruh positif dalam peningkatan kemampuan argumentasi ilmiah.

Pembelajaran menggunakan teknologi dapat berupa simulasi online. Simulasi online telah banyak dibuat agar melek informasi pada saat ini, sehingga perlu untuk mengembangkan beberapa komponen dan kegiatan interaktif terutama di bidang fisika (Parsazadeh, Ali, \& Rezaei, 2018). Simulasi virtual online sebanding atau lebih unggul dari metode simulasi tradisional di mana peningkatan keterlibatan dengan pembelajaran terjadi di lingkungan yang aman dengan akses 
yang mudah (Duff, Miller, \& Bruce, 2016). Dan juga, sebagai bagian dari tugas simulasi, masingmasing kelompok diharapkan untuk mengembangkan rencana strategis untuk membantu dalam proses pengambilan keputusan, dan seberapa baik mereka menyesuaikan diri dengan rencana strategis (Tee \& Karney, 2010). Dalam pengambilan keputusan, kemampuan argumentasi ilmiah menjadi komponen paling penting. Dengan demikian, kemampuan argumentasi ilmiah dapat ditingkatkan melalui penggunaan simulasi online.

Selain itu, kemampuan argumentasi ilmiah dapat ditingkatkan dengan pembelajaran kolaboratif. Dalam pembelajaran tersebut, siswa selain dapat bertukar pengetahuan tetapi juga dapat membangun pengetahuan baru dari ide orang lain. Selain itu, Ini dapat meningkatkan pemahaman siswa tentang sifat sosial membantah ilmu pengetahuan, serta penalaran berbasis bukti dan keterampilan berpikir kritis, sehingga memperkuat penilaian dan pengambilan keputusan siswa (Tsai, 2018). Salah satu pembelajaran yang kolaboratif adalah Pembelajaran menggunakan PBL.

Masalah yang disajikan dalam PBL terstruktur dengan baik dan kompleks, perincian yang diketahui tidak memberikan semua informasi yang diperlukan untuk memahami semua elemen masalah dan bagaimana itu berinteraksi. Ini memberikan tantangan-tantangan kepada siswa karena siswa untuk memahami masalah sepenuhnya dan dapat mengidentifikasi bukti yang tepat untuk mencari solusi (Belland, Glazewski, \& Richardson, 2011). Dengan demikian, menurut (Loyens, Jones, Mikkers, \& van Gog, 2015) PBL dapat memfasilitasi aktivasi pembentukan pengetahuan, analisis kritis argumen, dan mempromosikan pemahaman yang mendalam tentang perspektif ilmiah.

Penelitian ini berfokus pada peningkatan kemampuan agumentasi ilmiah. Peningkatan kemampuan argumentasi ilmiah dilakukan melalui model PBL berbantuan simulasi online. dengan demikian, tujuan penelitian ini untuk mengetahui efektivitas model PBL berbantuan simulasi online untuk meningkatkan kemampuan argumentasi ilmiah.

\section{METODE}

Jenis penelitian ini merupakan penelitian mix-method. Variabel penelitian berupa peningkatan kemampuan argumentasi ilmiah dianalisis secara kuantitatif. Sedangkan pola argumentasi siswa dalam menyelesaikan masalah dianalisis secara diskriptif kualitatif menggunakan pola argumen Toulmin. Desain penelitian ini adalah quasi experiment dengan pre-test dan post-test. Penelitian ini dilakukan pada bulan mei 2018 di SMA Negeri 1 Prambanan Yogyakarta dengan melibatkan 25 objek penelitian siswa kelas XI MIA 3.

Tipe data dalam penelitian ini adalah kuantitatif dan kualitatif. Data kuantitatif diperoleh dari skor tes kemampuan argumentasi ilmiah siswa. Data kualitatif diperoleh dari jawaban tes kemampuan argumentasi siswa yang dikoding menjadi pola argumentasi. Instrumen penelitian ini berupa lembar tes kemampuan argumentasi ilmiah. Teknik pengumpulan data dalam penelitian ini melalui tes berupa soal kemampuan argumentasi ilmiah pada materi mata dan kacamata.

Data tersebut dianalisis menggunakn uji paired sample T-test untuk membandingkan ratarata skor argumentasi ilmiah pada pre-test dan post-test. Peningkatan kemampuan argumentasi ilmiah dideskripsikan melalui peningkatan nilai rata-rata pada pre-test dan post-test. Pola argumentasi ilmiah siswa dianalisis secara deskriptif kualitatif berdasarkan pola argumen Toulmin pada Tabel 1.

Tabel 1. Pola Argumen Toulmin (TAP) yang dikembangkan olen Sampson, Enderle dan Walker (2012)

\begin{tabular}{cl}
\hline Level & \multicolumn{1}{c}{ Karakteristik Argumentasi } \\
\hline Level 5 & $\begin{array}{l}\text { Argumen-argumen yang luas dengan } \\
\text { lebih dari satu rebuttal. }\end{array}$ \\
Level 4 & $\begin{array}{l}\text { Argumen-argument dengan sebuah } \\
\text { claim dengan beberapa rebuttal yang } \\
\text { bisa diidentifikasikan dengan jelas. }\end{array}$ \\
Level 3 & $\begin{array}{l}\text { Argumen-argumen dengan rangkaian } \\
\text { claim atau counter-claim dengan data, } \\
\text { warrant, atau backing yang terkadang } \\
\text { disertai dengan rebuttal lemah. }\end{array}$ \\
Level 2 & $\begin{array}{l}\text { Argumen-argumen yang terdiri dari } \\
\text { claim dengan data, warrant atau } \\
\text { backing namun tanpa rebuttal. } \\
\text { Level 1 } \\
\text { Argumen-argumen sederhana yang } \\
\text { berupa claim vs counter-claim atau } \\
\text { claim vs claim }\end{array}$ \\
\hline
\end{tabular}

\section{HASIL DAN PEMBAHASAN}

\section{Peningkatan Kemampuan Argumentasi Ilmiah Siswa}

Berdasarkan hasil analisis skor argumentasi ilmiah siswa menggunakan paired sample $T$ test, hasil output paired sample statistic seperti terlihat pada Tabel 2. Pada Tabel 2, rata-rata pretest sebesar 14 meningkat menjadi sebesar 47 pada post-test. Meskipun nilai rata-rata tidak menunjukkan ketercapaian KKM, ini sudah menjadi 
pencapaian yang baik untuk meningkatkan nilai kemampuan argumentasi ilmiah. Nilai rata-rata yang dibawah KKM dapat terjadi karena disebabkan oleh desain pembelajaran PBL yang kurang memaksimalkan pembangunan argumen siswa serta siswa sulit memahami istilah-istilah pola argumentasi.

Tabel 2. Paired Samples Statistics

\begin{tabular}{llccc}
\hline & & Mean & N & Std. Deviation \\
\hline Pair & Pretest & 14,00 & 25 & 5,951 \\
1 & Postest & 47,00 & 25 & 13,617 \\
\hline
\end{tabular}

Tampilan peningkatan kemampuan argumentasi ilmiah siswa dapat dijelaskan melalui Gambar 1.

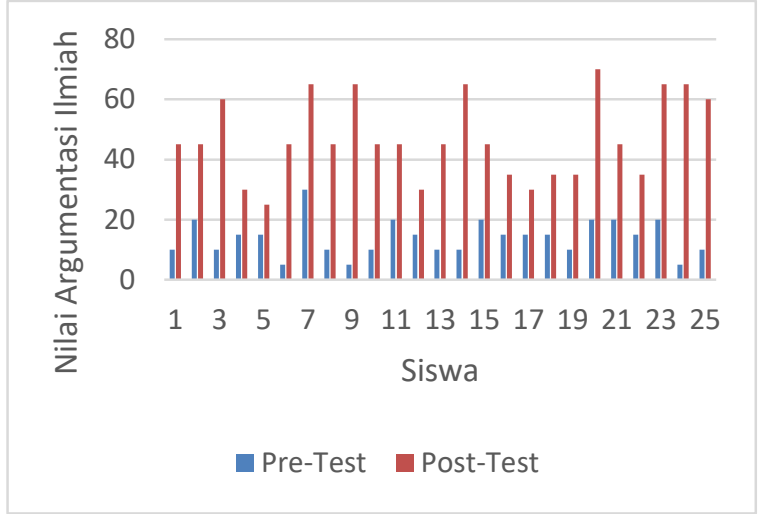

Gambar 1. Tampilan Kemampuan Argumentasi

Pada Gambar 1, nilai argumentasi ilmiah siswa mengalami peningkatan. Ini ditunjukkan oleh nilai Pre-test dan nilai Post-test siswa. Peningkatan tersebut tidak terlalu signifikan dan berada pada rentang yang konstan. Tidak ada jaminan bahwa nilai Pre-test yang tertinggi, akan memiliki nilai Post-test yang tertinggi. Namun, Peningkatan ini menunjukkan bahwa penerapan pembelajaran berbasis masalah berbantuan simulasi online efektif untuk meningkatkan kemampuan argumentasi ilmiah.

Pada hasil pengeluaran uji paired sample $T$-test dapat dilihat apakah terdapat perbedaan rata-rata pre-test dan post-test pada Tabel 3.

Tabel 3. Paired samples T-test

\begin{tabular}{llrr}
\hline & $\mathrm{t}$ & \multicolumn{2}{c}{ Df Sig. (2-tailed) } \\
\hline Pair 1 Pretest - Postest & $-11,051$ & 24 &, 000 \\
\hline
\end{tabular}

Dengan membandingkan nilai $\mathrm{t}$ hitung $(-11.051)<\mathrm{t}$ tabel $(-1.711)$, ini menunjukkan bahwa terdapat perbedaan nilai rata-rata argumentasi ilmiah pre-test dan post-test. Ini juga dibuktikan dengan nilai sig. 2-tailed $(0.000)<$ taraf signifikansi (0.05). Ini berarti bahwa pembelajaran berbasis masalah berbantuan $e d u$ - media simulasi berpengaruh terhadap peningkatan kemampuan argumentasi ilmiah siswa. Hasil ini selaras dengan penelitian Wibawa, Prayitno, dan Marjono bahwa pembelajaran berbasis masalah efektif untuk meningkatkan argumentasi ilmiah (Wibawa, Prayitno, \& Marjono, 2017).

Peningkatan argumentasi ilmiah siswa relevan dengan tahapan-tahapan pembelajaran berbasis masalah. Tahapan PBL membuat siswa ikut serta dalam penyelidikan (Belland et al., 2011) sehingga mampu menyajikan solusi permasalahan dalam argumentasi. Tahapan PBL juga menyajikan hasil penyelidikan berupa argumentasi sebagai praktik ilmiah untuk memecahkan masalah (Faize, Husain, \& Nisar, 2017). PBL juga mengorganisasikan siswa untuk memberikan prediksi jawaban dan hipotesis (Arends, 2012). Ini melatih siswa untuk membuat pernyataan atau claim.

\section{Karakteristik Kemampuan Argumentasi Siswa}

Jawaban Post-test siswa dianalisis menggunakan Pola Argumentasi Toulmin (TAP) yang di kelompokkan berdasarkan level-level. Pola Argumentasi Toulmin terdiri dari Claim $(C)$, Data $(D)$, Warrant $(W)$, Qualifier $(Q)$, CounterClaim (CC), Backing (B), dan Rebuttal (R) (Erduran, Simon, \& Osborne, 2004). Jika pola argumentasi siswa terdiri dari Claim, Data dan Warrant maka akan diberi kode C.D.W. jika pola argumentasi siswa terdiri dari Claim, Data, Warrant dan Backing maka akan diberi kode C.D.W.B. Hasil dan pembahasan karakteristik argumentasi siswa berdasarkan lima soal Posttest sebagai berikut:

\section{Kasus Penderita Cacat Mata Rabun Jauh}

Contoh kasus anak penderita rabun jauh ditunjukkan oleh Gambar 2 Siswa mengerjakan soal yang berhubungan dengan penderita cacat mata. Berdasarkan jawaban post-test siswa pada kasus ini, sebanyak $28 \%$ siswa memiliki argumentasi ilmiah pada level 1. Pola argumentasi yang muncul antara lain CW, DW dan W. Siswa yang memiliki argumentasi ilmiah pada level 2 sebanyak $44 \%$. Pola argumentasi yang muncul antara lain CDW dan CDWB. Siswa yang memiliki argumentasi ilmiah pada level 3 sebanyak $28 \%$. Pola argumentasi yang muncul antara lain C2DWR dan CDWBR.

"Saya setuju dengan pendapat Umi (C). Penderita miopi dapat dibantu dengan lensa cekung (D). Karena lensa cekung bersifat mengumpul- 
kan cahaya sehingga cahaya akan jatuh tepat pada retina (W). Saya tidak setuju dengan pendapat Rani $(R)$. Lensa cembung tidak dapat membantu penderita Miopi karena Menyebarkan Cahaya (D)".

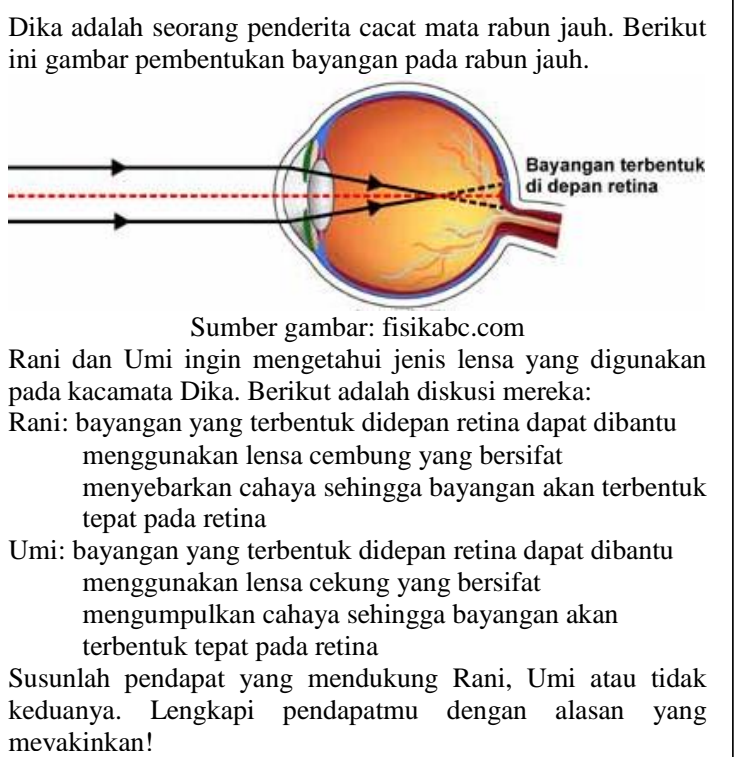

Gambar 2. Soal 1 Kasus Penderita Cacat Mata Rabun Jauh

Pada level ini, siswa mampu membuat rebuttal atau sanggahan terhadap pendapat yang lain. Namun Rebuttal yang dibuat masih lemah.

Kasus Penderita Cacat Mata Rabun Dekat

Rudi adalah seorang penderita cacat mata rabun Dekat. Berikut ini gambar pembentukan bayangan pada rabun Dekat.

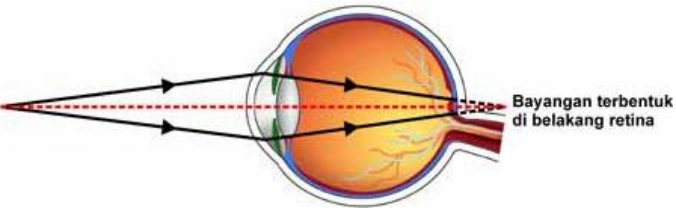

Sumber Gambar: fisikabc.com

Dedi dan Ihsan ingin mengetahui jenis lensa yang digunakan pada kacamata Rudi. Berikut adalah diskusi mereka:

Dedi: bayangan yang terbentuk dibelakang retina dapat dibantu menggunakan lensa cekung yang bersifa mengumpulkan cahaya sehingga bayangan akan terbentuk tepat pada retina

Ihsan: bayangan yang terbentuk dibelakang retina dapa dibantu menggunakan lensa cembung yang bersifat menyebarkan cahaya sehingga bayangan akan terbentuk tepat pada retina

Susunlah pendapat yang mendukung Dedi, Ihsan atau tidak keduanya. Lengkapi pendapatmu dengan alasan yang meyakinkan!

Gambar 3. Soal 2 Kasus Penderita Cacat Mata Rabun Jauh

Contoh kasus anak penderita rabun dekat ditunjukkan oleh Gambar 3, siswa mengerjakan soal yang berhubungan dengan penderita cacat mata. Berdasarkan jawaban Post-test siswa pada kasus ini, sebanyak $44 \%$ siswa memiliki argumentasi ilmiah pada level 1. Pola argumentasi yang muncul antara lain CW, DW dan W. Siswa yang memiliki argumentasi ilmiah pada level 2 sebanyak $32 \%$. Pola argumentasi yang muncul antara lain CDW dan CDWB. Siswa yang memiliki argumentasi ilmiah pada level 3 sebanyak $24 \%$. Pola argumentasi yang muncul antara lain CDWR dan CDWBR

Kasus Menghitung Kekuatan Lensa Mata untuk Mengatasi Cacat Mata Rabun Dekat

Contoh kasus menghitung Kekuatan Lensa Mata untuk mengatasi cacat mata ditunjukkan oleh Gambar 4, siswa mengerjakan soal yang berhubungan dengan kekuatan lensa mata.

Pak Romi sering merasa kesulitan melihat benda dengan jelas
pada jarak lebih kecil $60 \mathrm{~cm}$ dari mata. Pak Romi ingin
membaca jarak benda $30 \mathrm{~cm}$. Dodi dan Sinta yang merupakan
anak pak Romi, ingin memprediksi kekuatan lensa kacamata
yang akan digunakan ayahnya sebelum konsultasi ke dokter.
Berikut adalah diskusi mereka:
Dodi: Dengan menggunakan persamaan umum lensa, jarak
fokus lensanya $60 \mathrm{~cm}$ dan kekuatan lensanya adalah $1 / 60$
Dioptri.
Sinta: Dengan menggunakan persamaan umum lensa, jarak
fokus lensanya 20 m dan kekuatan lensanya adalah $1 / 20$
Dioptri.
Susunlah pendapat yang mendukung Dodi, Sinta atau tidak
keduanya. Lengkapi pendapatmu dengan alasan yang
meyakinkan!

Gambar 4. Soal 3 Kasus Penderita Cacat Mata Rabun Jauh

Berdasarkan jawaban post-test siswa pada kasus ini, sebanyak $12 \%$ siswa tidak menjawab soal ini. Dan sebanyak 16\% siswa memiliki argumentasi ilmiah pada level 1. Pola argumentasi yang muncul antara lain CB dan B. Siswa yang memiliki argumentasi ilmiah pada level 2 sebanyak $64 \%$. Pola argumentasi yang muncul antara lain CDW, CDB dan CDWB. Siswa yang memiliki argumentasi ilmiah pada level 3 sebanyak $8 \%$. Pola argumentasi yang muncul antara lain CDWR dan CDWBR.

Kasus Menghitung Kekuatan Lensa Mata untuk Mengatasi Cacat Mata Rabun Jauh

Contoh kasus menghitung kekuatan lensa mata untuk mengatasi cacat mata ditunjukkan oleh Gambar 5, siswa mengerjakan soal yang berhubungan dengan kekuatan lensa mata. 
Faris memiliki titik jauh $17 \mathrm{~cm}$. Nana dan Danu ingin memrediksi kekuatan lensa kacamata yang digunakan Faris sehingga dapat melihat benda jauh dengan jelas. Dengan asumsi lensa kacamata berada $2 \mathrm{~cm}$ dari mata. Berikut adalah diskusi mereka:

Nana: Dengan menggunakan persamaan umum lensa, jarak fokusnya $-15 \mathrm{~cm}$ dan kekuatan lensanya adalah $-1 / 15$ Dioptri

Danu: Dengan menggunakan persamaan umum lensa, jarak fokus lensanya $-17 \mathrm{~cm}$ dan kekuatan lensanya adalah $-1 / 17$ Dioptri

Susunlah pendapat yang mendukung Nana, Danu atau tidak keduanya. Lengkapi pendapatmu dengan alasan yang meyakinkan!

Gambar 5. Soal 4 Kasus Penderita Cacat Mata Rabun Jauh

Berdasarkan jawaban post-test siswa pada kasus ini, sebanyak 24\% siswa tidak menjawab soal ini. Dan sebanyak 28\% siswa memiliki argumentasi ilmiah pada level 1. Pola argumentasi yang muncul antara lain $\mathrm{C}, \mathrm{CB}, \mathrm{CD}, \mathrm{DWB}$ dan CW. Dalam hal ini siswa mampu membuat claim dan beberapa yang disertai backing, data atau warrant. Selain itu, juga terdapat siswa yang tidak dapat membuat klaim namun menyajikan data, warrant dan backing. Siswa yang memiliki argumentasi ilmiah pada level 2 sebanyak 40\%. Pola argumentasi yang muncul antara lain CDW dan CDWB. Siswa yang memiliki argumentasi ilmiah pada level 3 sebanyak 8\%. Pola argumentasi yang muncul antara lain CDWR dan CDWBR.

Kasus Hubungan Bentuk Lensa dan Akomodasi Mata

Contoh kasus hubungan bentuk lensa dan akomodasi mata ditunjukkan oleh Gambar 6, siswa mengerjakan soal yang berhubungan dengan akomodasi mata. Berdasarkan jawaban post-test siswa pada kasus ini, sebanyak $60 \%$ siswa memiliki argu-mentasi ilmiah pada level 1. Pola argumentasi yang muncul antara lain C, D, $\mathrm{W}$ dan CW. Siswa yang memiliki argumentasi ilmiah pada level 2 sebanyak 24\%. Pola argumentasi yang muncul antara lain CDW dan CDWB. Siswa yang me-miliki argumentasi ilmiah pada level 3 sebanyak 16\%. Pola argumentasi yang muncul antara lain CDWR dan CDWBR.

Pada level 1, siswa mampu menyajikan klaim, data atau alasan saja. Pada level 2, Siswa sudah mampu membuat klaim yang tegas dengan menyajikan bukti dan alasan namun kurang mendukung klaim. Pada level 3, siswa mampu membuat rebuttal atau sanggahan terhadap pendapat yang lain. Namun Rebuttal yang dibuat masih lemah. Kemampuan argumentasi siswa sudah mencapai level 3, siswa sudah mampu membuat klaim, data, alasan dan sanggahan. Namun data, alasan dan sanggahan yang disajikan masih belum kuat untuk mendukung klaim. Ini sejalan dengan (Wardani, Yuliati, \& Taufiq, 2016) menyatakan bahwa sebagian besar siswa mampu membuat klaim dengan alasan yang kurang mendukung klaim. Selain itu, (Rahman, Diantoro, \& Yuliati, 2018) juga menyatakan siswa cenderung mampu membuat klaim namun data atau alasan yang disajikan kurang relevan.

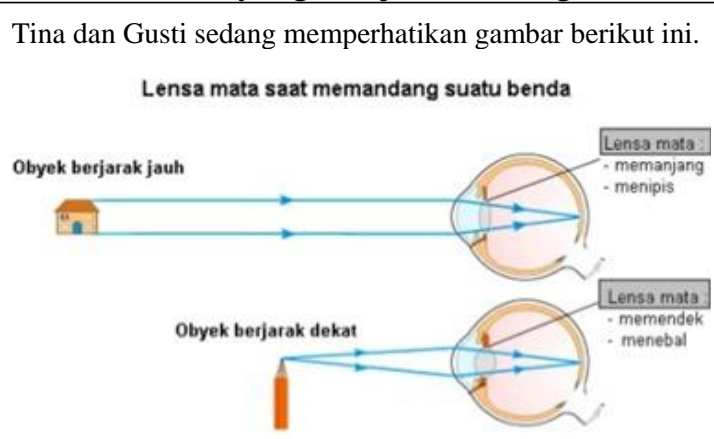

Tina dan Gusti ingin mengetahui hubungan bentuk lensa dan kondisi mata berakomodasi atau tidak berakomodasi. Berikut adalah diskusi mereka.

Tina: ketika mata memandang benda berjarak dekat, lensa mata akan memendek dan menebal sehingga kondisi mata relaks (tidak berakomodasi)

Gusti: ketika mata mendang objek berjarak jauh, lensa mata akan memanjang dan menipis sehingga kondisi otot mata menegang (berakomodasi)

Susunlah pendapat yang mendukung Tina, Gusti atau tidak keduanya. Lengkapi pendapatmu dengan alasan yang meyakinkan!

Gambar 6. Soal 5 Kasus Penderita Cacat Mata Rabun Jauh

Terdapat beberapa alasan yang menyebabkan kemampuan argumentasi ilmiah siswa masih pada level rendah. Siswa mengalami kesulitan untuk membuat argumentasi yang terstruktur berdasarkan konsep ilmiah (teori, prinsip dan hukum). Mereka juga belum memahami komponen argumentasi ilmiah yang benar. Alasan lain dapat berupa penggunaan data yang terbatas untuk mendukung klaim (Sampson \& Clark, 2011), serta menggunakan alasan atau sanggahan yang tidak mereka pahami (Martín-Gámez \& Erduran, 2018).

\section{SIMPULAN}

Berdasarkan hasil dan diskusi, dinyatakan bahwa terdapat perbedaan yang signifikan antara nilai rata-rata kemampuan argumentasi ilmiah pada pre-test dan post-test setelah dilakukan pembelajaran berbasis masalah menggunakan simulasi online. Selain itu, juga terjadi pening- 
katan nilai rata-rata kemampuan argumentasi siswa. Dengan demikian, pembelajaran berbasis masalah dengan bantuan simulasi online efektif untuk meningkatkan kemampuan argumentasi ilmiah siswa. Dalam hal ini, siswa sudah mampu membuat klaim yang tegas dengan menyajikan bukti, alasan dan sanggahan, namun kurang mendukung klaim.

\section{DAFTAR PUSTAKA}

Ault, M., Craig-Hare, J., Frey, B., Ellis, J. D., \& Bulgren, J. (2015). The effectiveness of reason racer, a game designed to engage middle school students in scientific argumentation. Journal of Research on Technology in Education, 47(1), 21-40. https://doi.org/10.1080/15391523.2015.96 7542

Aydeniz, M., \& Ozdilek, Z. (2015). Assessing pre- service science teachers' understanding of scientific argumentation: What do they know about argumentation after four years of college science? Science Education International, 26(2), 217-239.

Bathgate, M., Crowell, A., Schunn, C., Cannady, M., \& Dorph, R. (2015). The learning benefits of being willing and able to engage in scientific argumentation. International Journal of Science Education, 37(10), 1590-1612. https://doi.org/10.1080/09500693.2015.10 45958

Belland, B. R., Glazewski, K. D., \& Richardson, J. C. (2011). Problem-based learning and argumentation: testing a scaffolding framework to support middle school students' creation of evidence-based arguments. Instructional Science, 39(5), 667-694. https://doi.org/10.1007/s11251010-9148-z

Berland, L. K., \& McNeill, K. L. (2010). A learning progression for scientific argumentation: Understanding student work and designing supportive instructional contexts. Science Education, 94(5), 765-793. https://doi.org/10.1002/sce.20402

Chien, Y.-T., \& Chang, C.-Y. (2015). Supporting socio-scientific argumentation in the classroom through automatic group formation based on students' real-time responses. In Science Education in East Asia (pp. 549-563). Cham: Springer International
Publishing. https://doi.org/10.1007/978-3-319-16390$1 \_22$

Clark, D., Sampson, V., Stegmann, K., Marttunen, M., Kollar, I., Janssen, J., ... Laurinen, L. (2010). Online learning environments, scientific argumentation, and 21 st Century skills. In E-Collaborative Knowledge Construction: Learning from Computer-Supported and Virtual Environments (pp. 1-39). https://doi.org/10.4018/978-1-61520-7299.ch001

Duff, E., Miller, L., \& Bruce, J. (2016). Online virtual simulation and diagnostic reasoning: A scoping review. Clinical Simulation in Nursing, 12(9), 377-384. https://doi.org/10.1016/j.ecns.2016.04.001

Erduran, S., Simon, S., \& Osborne, J. (2004). TAPping into argumentation: Developments in the application of Toulmin's Argument Pattern for studying science discourse. Science Education, $88(6)$, 915-933. https://doi.org/10.1002/sce.20012

Faize, F. A., Husain, W., \& Nisar, F. (2017). A critical review of scientific argumentation in science education. Eurasia Journal of Mathematics, Science and Technology Education, 14(1), 475-483. https://doi.org/10.12973/ejmste/80353

Heng, L. L., Surif, J., \& Seng, C. H. (2015). Malaysian students' scientific argumentation: Do groups perform better than individuals? International Journal of Science Education, 37(3), 505-528. https://doi.org/10.1080/09500693.2014.99 5147

Hsu, P.-S., Van Dyke, M., Smith, T. J., \& Looi, C.-K. (2018). Argue like a scientist with technology: the effect of within-gender versus cross-gender team argumentation on science knowledge and argumentation skills among middle-level students. Educational Technology Research and Development, 66(3), 733-766. https://doi.org/10.1007/s11423-018-95741

Katsh-Singer, R., Mcneill, K. L., \& Loper, S. (2016). Scientific argumentation for all? Comparing teacher beliefs about argumentation in high, mid, and low socioeconomic status schools. Science Education, $\quad$ 100(3), 410-436. 
https://doi.org/10.1002/sce.21214

Loyens, S. M. M., Jones, S. H., Mikkers, J., \& van Gog, T. (2015). Problem-based learning as a facilitator of conceptual change. Learning and Instruction, 38, 3442 .

https://doi.org/10.1016/j.learninstruc.2015 .03 .002

Manz, E. (2015). Representing student argumentation as functionally emergent from scientific activity. Review of Educational Research, 85(4), 553-590. https://doi.org/10.3102/003465431455849 0

Martín-Gámez, C., \& Erduran, S. (2018). Understanding argumentation about socioscientific issues on energy: a quantitative study with primary pre-service teachers in Spain. Research in Science \& Technological Education, 1-21. https://doi.org/10.1080/02635143.2018.14 27568

Mubarok, O. S., Muslim, M., \& Danawan, A. (2016). Pengaruh model pembelajaran berbasis masalah dengan pendekatan saintifik terhadap kemampuan argumentasi ilmiah siswa SMA pada materi pengukuran. Prosiding SNPS (Seminar Nasional Pendidikan Sains), 3(0), 381-388. Retrieved from http://jurnal.fkip.uns.ac.id/index.php/snps/ article/view/9862

Muliardi, M. W. R., Supeno, S., \& Bektiarso, S. (2018). Lembar kerja siswa scientific explanation untuk melatihkan kemampuan penjelasan ilmiah siswa SMA dalam pembelajaran fisika. In Prosiding Seminar Nasional Pendidikan Fisika (Vol. 3, pp. 33-38). Retrieved from https://jurnal.unej.ac.id/index.php/fkipepro/article/view/7366

Parsazadeh, N., Ali, R., \& Rezaei, M. (2018). A framework for cooperative and interactive mobile learning to improve online information evaluation skills. Computers \& Education, 120, 75-89. https://doi.org/10.1016/j.compedu.2018.0 1.010

Putri, R. E. (2018). Meningkatkan kemampuan argumentasi ilmiah siswa SMP Kelas VII melalui bahan ajar IPA terpadu dengan tema HALO pada topik kalor. SEMESTA: Journal of Science Education and
Teaching, $\quad 1(1), \quad 34$. https://doi.org/10.24036/semesta/vol1iss $1 / 10$

Rahman, A., Diantoro, M., \& Yuliati, L. (2018). Kemampuan argumentasi ilmiah siswa pada hukum Newton di sekolah menengah atas. Jurnal Pendidikan: Teori, Penelitian, Dan Pengembangan, 3(7), 903-911. https://doi.org/10.17977/JPTPP.V3I7.113 37

Saavedra, A. R., \& Opfer, V. D. (2012). Learning 21 st-Century skills requires 21 st-Century teaching. Phi Delta Kappan, 94(2), 8-13. https://doi.org/10.1177/003172171209400 203

Sampson, V., \& Clark, D. B. (2011). A comparison of the collaborative scientific argumentation practices of two high and two low performing groups. Research in Science Education, 41(1), 63-97. https://doi.org/10.1007/s11165-009-91469

Sudarmo, N. A., Lesmono, A. D., \& Harijanto, A. (2018). Analisis kemampuan berargumentasi ilmiah siswa SMA pada konsep termodinamika. Jurnal Pembelajaran Fisika, 7(2), 196-201. https://doi.org/10.19184/jpf.v7i2.7928

Tee, M. Y., \& Karney, D. (2010). Sharing and cultivating tacit knowledge in an online learning environment. International Journal of Computer-Supported Collaborative Learning, 5(4), 385-413. https://doi.org/10.1007/s11412-010-90953

Tsai, C.-Y. (2018). The effect of online argumentation of socio-scientific issues on students' scientific competencies and sustainability attitudes. Computers \& Education, 116, 14-27. https://doi.org/10.1016/j.compedu.2017.0 8.009

von Aufschnaiter, C., Erduran, S., Osborne, J., \& Simon, S. (2008). Arguing to learn and learning to argue: Case studies of how students' argumentation relates to their scientific knowledge. Journal of Research in Science Teaching, 45(1), 101-131. https://doi.org/10.1002/tea.20213

Wardani, A. D., Yuliati, L., \& Taufiq, A. (2016). Kemampuan argumentasi ilmiah dan pemecahan masalah fisika siswa SMA pada materi gaya dan gerak. In Prosiding 


\section{Jurnal Inovasi Pendidikan IPA, 5 (1), 2019 - 53}

Riwayani Riwayani, Riki Perdana, Ratna Sari, Jumadi Jumadi, Heru Kuswanto

Seminar Nasional Pendidikan IPA Pascasarjana UM. Malang: Universitas Negeri Malang. Retrieved from http://pasca.um.ac.id/wpcontent/uploads/2017/02/Adetya-Dewi13-28.pdf

Wibawa, R. A. P., Prayitno, B. A., \& Marjono, M. (2017). Penerapan problem based learning pada materi pencemaran lingkungan untuk meningkatkan kemampuan argumentasi ilmiah tertulis siswa kelas X MIPA. In Proceeding Biology Education Conference: Biology, Science, Enviromental, and Learning (Vol. 14, p. 361). Retrieved from https://jurnal.uns.ac.id/prosbi/article/view/ 18808

Yacoubian, H. A., \& Khishfe, R. (2018). Argumentation, critical thinking, nature of science and socioscientific issues: a dialogue between two researchers. International Journal of Science Education, 40(7), 796-807. https://doi.org/10.1080/09500693.2018.14 49986

Yun, S. M., \& Kim, H. B. (2015). Changes in students' participation and small group norms in scientific argumentation. Research in Science Education, 45(3), 465-484. https://doi.org/10.1007/s11165014-9432-Z

Zhu, M., Lee, H.-S., Wang, T., Liu, O. L., Belur, V., \& Pallant, A. (2017). Investigating the impact of automated feedback on students' scientific argumentation. International Journal of Science Education, 39(12), 1648-1668.

https://doi.org/10.1080/09500693.2017.13 47303 